\title{
FIELD OBSERVATIONS ON RARE OR OVERLOOKED dinoflagellates from the Argentine Sea
}

\author{
OBSERVACIONES DE CAMPo SOBRE DINOFLAGELADOS RAROS O \\ desconocidos en el Mar Argentino
}

\author{
Elena Fabro ${ }^{1,2 *}$ (D) \& Gastón O. Almandoz ${ }^{1,2}$ (D)
}

\begin{abstract}
1. División Ficología, Facultad de Ciencias Naturales y Museo, Universidad Nacional de La Plata. Paseo del Bosque s/n (B1900FWA), La Plata, Argentina.

2. Consejo Nacional de Investigaciones Científicas y Técnicas (CONICET). Godoy Cruz 2290 (C1425FQB), Buenos Aires, Argentina.
\end{abstract}

\section{*fabroelena@yahoo.com.ar}

Citar este artículo FABRO, E. \& G. O. ALMANDOZ. 2021. Field observations on rare or overlooked dinoflagellates from the Argentine Sea. Bol. Soc. Argent. Bot. 56: 123-140.

DOI: https://doi. org/10.31055/1851.2372.v56. n2.31421

Recibido: 15 Dic 2020

Aceptado: 17 May 2021

Publicado impreso: 30 Jun 2021

Editora: Sylvia Bonilla (iD

ISSN versión impresa 0373-580X ISSN versión on-line 1851-2372

\section{SUMMARY}

Background and aims: Planktonic dinoflagellates have a great ecological significance in marine environments. While some dinoflagellate species commonly reach bloom concentrations and are thus conspicuous components of marine phytoplankton, others occur in very low abundances which make them difficult to detect in field studies. Here we analyzed dinoflagellate composition and abundance in five oceanographic expeditions carried out in continental shelf and slope waters of the Argentine Sea.

M\&M: Plankton abundance was estimated by the Utermöhl method, using inverted microscopy, whereas further optical and scanning electron microscopy was applied for the identification of dinoflagellate species.

Results: We focused on the occurrence of seven dinoflagellates that have been previously poorly documented or overlooked in marine environments worldwide: Dinophysis microstrigiliformis; Gyrodinium sp.; Karlodinium elegans; Oxytoxum laticeps; Peridiniella danica; Peridiniella globosa and Prorocentrum nux. The latest and $K$. elegans are observed for the first time in field conditions after their original descriptions based on cell cultures. While most species were detected in low or moderate abundances, $P$. nux, which is the smallest Prorocentrum species, reached 82,000 cells $\mathrm{L}^{-1}$ in slope waters. Very small Gyrodinium cells $(11.5 \mu \mathrm{m}$ long; $8.7 \mu \mathrm{m}$ wide) with a distribution restricted to slope waters during spring, were not possible to be accurately assigned to a species.

Conclusions: This study contributes to the understanding of dinoflagellate diversity in the Argentine Sea and the worldwide distribution of little known species.

\section{Key Words}

Biogeography, dinoflagellates, diversity, Karlodinium elegans, Prorocentrum nux, South Atlantic Ocean.

\section{Resumen}

Introducción y objetivos: Los dinoflagelados planctónicos son de gran relevancia en los ecosistemas marinos. Mientras que algunas especies suelen forman floraciones y ser componentes conspicuos del fitoplancton, otras se encuentran en abundancias muy bajas, lo cual hace difícil su detección. Aquí analizamos la composición y abundancia de dinoflagelados en cinco expediciones oceanográficas realizadas en aguas de la plataforma continental y del talud del Mar Argentino.

M\&M: La abundancia se estimó con microscopio invertido (método Utermöhl) y se utilizó microscopía óptica y electrónica de barrido para la identificación específica.

Resultados: Nos enfocamos en la ocurrencia de siete dinoflagelados que previamente han sido poco documentados en ambientes marinos de todo el mundo: Dinophysis microstrigiliformis; Gyrodinium sp.; Karlodinium elegans; Oxytoxum laticeps; Peridiniella danica; Peridiniella globosa y Prorocentrum nux. Esta última especie y $\mathrm{K}$. elegans se observan por primera vez en el campo desde su descripción basada en cultivos celulares. Si bien la mayoría de las especies se detectaron en abundancias bajas o moderadas, $P$. nux, el Prorocentrum más pequeño, alcanzó 82.000 células $\mathrm{L}^{-1}$ en aguas del talud. Células pequeñas de Gyrodinium sp. (11,5 $\mu \mathrm{m}$ de largo y 8,7 $\mu \mathrm{m}$ de ancho), con un una distribución restringida a las aguas del talud durante la primavera, no pudieron ser asignadas con precisión a nivel específico.

Conclusiones: Este estudio contribuye al conocimiento de la diversidad de dinoflagelados en el Mar Argentino y la distribución mundial de especies poco conocidas.

\section{Palabras Clave}

Biogeografía, dinoflagelados, diversidad, Karlodinium elegans, Océano Atlántico Sur, Prorocentrum nux. 


\section{INTRODUCTION}

Planktonic microalgae comprise an essential biotic component of the world oceans. Among microalgae, dinoflagellates are of great ecological significance as they contribute to primary production and are determinant in trophic webs, representing a strong influence in biogeochemical cycles and biotic interactions (Graham \& Wilcox, 2000). Moreover, dinoflagellates include the largest number of toxigenic species among marine phytoplankton, which can produce harmful blooms with negative impacts to human health and marine life and generate economic losses to fisheries, aquaculture and exploitation of natural mussel's beds (Lassus et al., 2016).

Dinoflagellates are ubiquitous in marine environments; comprising heterotrophic, autotrophic and mixotrophic species and also ecto- and endoparasitic species and symbionts (Hackett et al., 2004). According to the presence or absence of cellulose inside the amphiesmal vesicles they are divided in two big groups: thecate and unarmored dinoflagellates. Within the thecate group taxonomical classification is based on the number, position and shape of the thecal plates, while in the unarmored group cellular shape, ultra-structural characters of the flagellar apparatus and shape of the apical groove are usually used to differentiate genera (Daugbjerg et al., 2000). With the advent of molecular technics in the last decades, phylogeny and morphological traits for classification of some unarmored dinoflagellates were reconsidered (Daugbjerg et al., 2000).

An important contribution to knowledge about the diversity and distribution of dinoflagellates, not only in the South Atlantic Ocean but also worldwide, comes from the copious work done by E. Balech (e.g. Balech, 1976, 1988, 1995, 2002). More recent studies have continued this line of research in the Argentine Sea, mainly covering coastal areas or toxigenic species (e.g. Akselman 1985, 1986, 1987; Akselman \& Negri, 2012; Akselman et al., 2015; Fabro et al., 2015; Antacli et al., 2018; Tillmann et al., 2019; Sunesen et al., 2020a). However, the recent description of new dinoflagellate species (Tillmann \& Akselman, 2016; Boutrup et al., 2017; Tillmann, 2018; Tillmann et al. 2018; Sunesen et al., 2020b) and the finding of new records (e.g. Fabro et al., 2016, 2017, 2019; Tillmann et al.,
2016) suggest that dinoflagellate diversity in the Argentine Sea is higher than previously known.

While some dinoflagellate species commonly reach bloom concentrations and are thus conspicuous components of marine phytoplankton, others occur in very low abundances which make them difficult to detect in field studies (Steidinger \& Tangen, 1997). Within this low-abundance species, small thecate and unarmored dinoflagellates are less studied in field conditions, as most of the research is directed to bigger armoured species with easily preserved morphological features (De Salas et al., 2008). In order to increase knowledge on dinoflagellate diversity in the Argentine Sea, we focused on the occurrence of small and rare dinoflagellates previously overlooked or poorly documented, by the analysis of plankton samples obtained in five oceanographic expeditions in different seasons. Based on detailed light and electron microscopy observations, we found cells of seven dinoflagellates that are poorly documented or found for the first time in the Southeast Atlantic Ocean and have also been rarely mentioned from marine environments worldwide. For each taxa we provide a detailed morphological characterization and describe their distribution patterns, compared with previous observations.

\section{Materials and Methods}

\section{Field Sampling}

The continental shelf and slope waters of the Argentine Sea were sampled during five oceanographic expeditions (Fig. 1). Expedition 1 (E1) was conducted in austral autumn on board the $R / V$ Puerto Deseado from March 30th to April 14th, 2012. A total of 47 stations were sampled between $\approx 38$ and $56^{\circ} \mathrm{S}$. The second expedition (E2) was carried out in late austral summer on the $R / V$ Bernardo Houssay from March 11th to March 22nd, 2013, with 24 sampling stations located between $\approx 39$ and $43{ }^{\circ} \mathrm{S}$. This cruise was divided in two legs $\mathrm{K} 1$ and $\mathrm{K} 2$, which comprise 8 and 16 sampling stations, respectively. The third expedition (E3) was conducted in austral spring aboard the $R / V$ Puerto Deseado, from October 26th to November 9th, 2013, with 47 sampling stations located between $\approx 40$ and $47^{\circ} \mathrm{S}$. The fourth expedition (E4) was conducted on board the 


\section{E. Fabro \& G. O. Almandoz - Rare marine dinoflagellates}
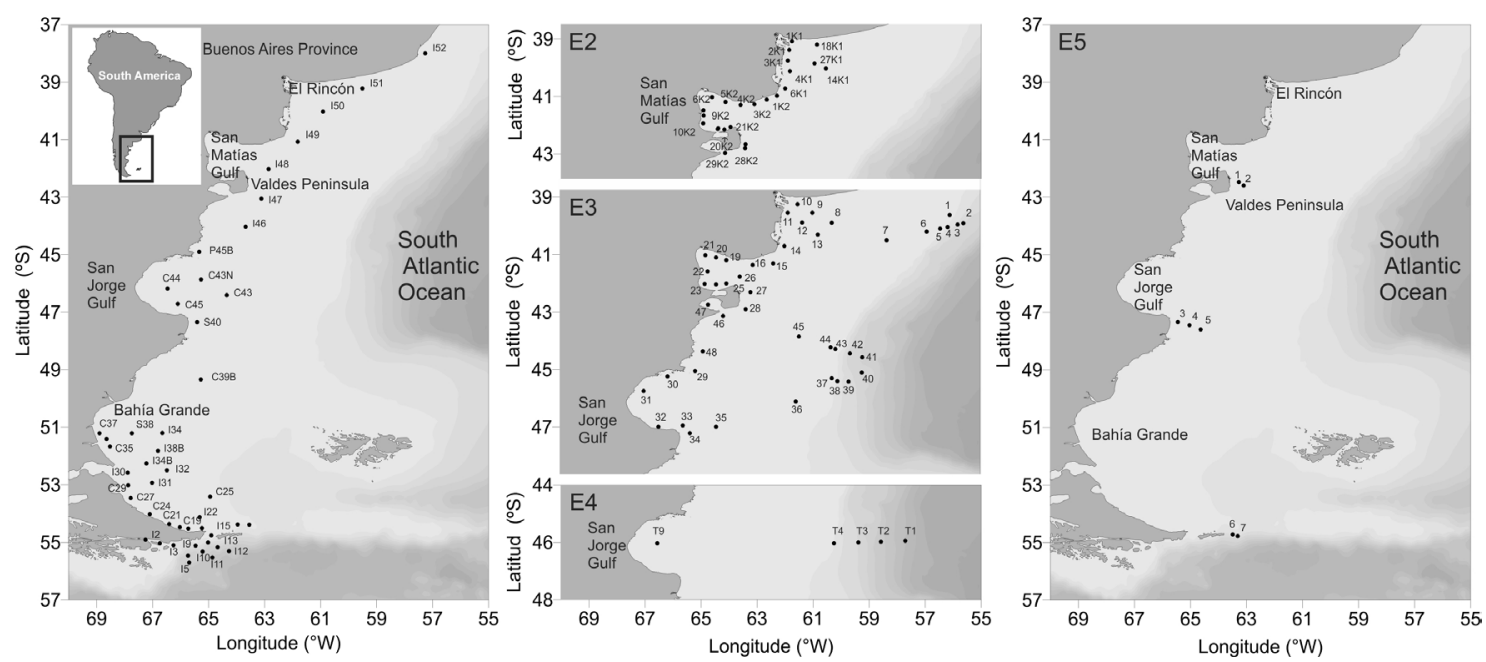

Fig. 1. Letters and numbers on maps indicate various sampling sites. Expeditions across the Argentine Sea. E1: autumn; E2: late summer; E3: spring; E4 and E5: summer.

Canadian $R / V$ Coriolis $I I$ in austral summer from 30th January to 15th February 2014, in a transect consisting of 5 sampling stations from internal shelf waters of San Jorge Gulf to slope waters in front of the gulf. The last expedition (E5) was carried out in austral summer from January 6th to January 12th, 2016, with seven sampling stations located between $\approx 38$ and $55^{\circ} \mathrm{S}$. The conductivity (salinity)/temperature/depth (CTD) data were available throughout all expeditions, except from leg K2 of expedition E2, during which no CTD measurements were performed. During this leg, only surface water temperature was measured with a multiparameter probe TOA-DKK Model WQC.

During all expeditions, Niskin bottle samples were taken from surface water ( $\sim 4 \mathrm{~m}$ depth). Aliquots of $250 \mathrm{~mL}$ were fixed with acidic Lugol's iodine solution for quantitative analyses. Plankton net samples were additionally collected for qualitative morphological analysis by vertical net tows through the upper $20 \mathrm{~m}$ of the water column with a $20 \mu \mathrm{m}$-mesh Nitex net and fixed with acidic Lugol's iodine solution.

\section{Plankton analysis}

Nano- $(\approx 5-20 \mu \mathrm{m})$ and microplankton $(20-200$ $\mu \mathrm{m})$ abundance was estimated using the Utermöhl (1958) inverted microscope method. Subsamples $(50 \mathrm{~mL})$ from the mixed water obtained by Niskin bottles were left to settle for $24 \mathrm{~h}$ in a composite sedimentation chamber prior to cell counting under an inverted microscope (Leica DMIL LED). The organisms were counted in two stages; at least 400 cells of the dominant taxa were counted in random fields or in transects of the chamber to estimate general plankton composition, whereas the whole chamber bottom was scanned to count sparse species.

Further morphological examination of selected samples was conducted with a phase contrast/differential interference contrast optical microscope (LM) Leica DM2500 equipped with a DFC420C camera, and with scanning electron microscopy (SEM): Jeol JSM-6360 LV SEM (JEOL, Tokyo, Japan), Carl Zeiss NTS SUPRA 40 (Zeiss, Oberkochen, Germany) and FEI Quanta FEG 200 (FEI, Eindhoven, the Netherlands). Bottle and net sample aliquots were filtered through 0.2 $\mu \mathrm{m}$ polyamide filters and $3 \mu \mathrm{m}$ polycarbonate filters for SEM analyses. The material on the filters was dehydrated by serial ethanol treatment and final critical point dehydration (BAL-TEC CPD-30, Balzers, Liechtenstein). Specimens were sputter-coated with $\mathrm{Au}$ with a sputter fine coat Jeol JFC 1.100 (Jeol, Tokyo, Japan) for samples observed with Jeol JSM-6360 LV SEM or with gold-palladium (Cressington Scientific Instruments, Watford, UK and Emscope SC500; Ashford, UK) for samples observed with Carl Zeiss NTS SUPRA 40 and FEI Quanta FEG 200. 


\section{Results AND Discussion}

Dinophysis microstrigiliformis Abé, Publ. Seto Mar. Biol. Lab. 15. 1967, Fig. 2.

Balech 1988, p. 230, lám. 8. Figs. 12-13.

Cells with elongated shape, longer than wide. The left sulcal list (LSL) is long, extending until the posterior end of the cell. The three ribs from the LSL are thin, $\mathrm{R} 3$ is shorter than $\mathrm{R} 2$ and the distance between $\mathrm{R} 2$ and $\mathrm{R} 3$ is larger than between $\mathrm{R} 1$ and $\mathrm{R} 2$ (Fig. 2A). The anterior cingular list (ACL) is smooth and conic (Fig. 2B). Dinophysis species are mixotrophic with cryptophycean-like plastids (Schnepf \& Elbräichter, 1988). Dimensions: length average $36.4 \mu \mathrm{m} \pm 3.5$, width average $21.3 \mu \mathrm{m} \pm 2.5(n=8)$.

Distribution and habitat. D. microstrigiliformis is a very rare species, which has been mentioned only a few times worldwide and always in very low abundances. According to Ivin et al. (2014) is probably a neritic and boreal species recorded near the coast of northern Japan and in Avacha Bay, Russia.
But the species has been found in the Southern Atlantic in some occasions. Haraguchi \& Odebrecht (2010) found one cell in internal shelf waters from Southern Brazil $\left(\approx 34{ }^{\circ} \mathrm{S}, 51^{\circ} \mathrm{W}\right)$ during winter. In the Argentine Sea, records of the species correspond to one cell found in external shelf waters in front of Buenos Aires Province $\left(37^{\circ} \mathrm{S}\right)$ and a few more thecae at $41^{\circ} \mathrm{S}$ (Balech et al., 1984; Balech, 1988). In our study, D. microstrigiliformis was only detected in net tow samples and it was confined to the southern Argentine Sea $\left(\approx 55^{\circ} \mathrm{S}\right)$ during autumn (Table 1), which supports its distribution in polar and sub-polar waters.

Observations. This species was described based on one cell from Japan (Abé, 1967). The author stated that it may be an aberrant form of D. lapidistrigiliformis, with smaller and more elongated theca, and longer LSL. Balech (1988) found also one cell from the northern Argentinean Sea $\left(37^{\circ} \mathrm{S}\right)$ and remarked that $D$. microstrigiliformis is very similar to $D$. sacculus, but with a longer LSL and a regular and convex dorsal edge. Dinophysis
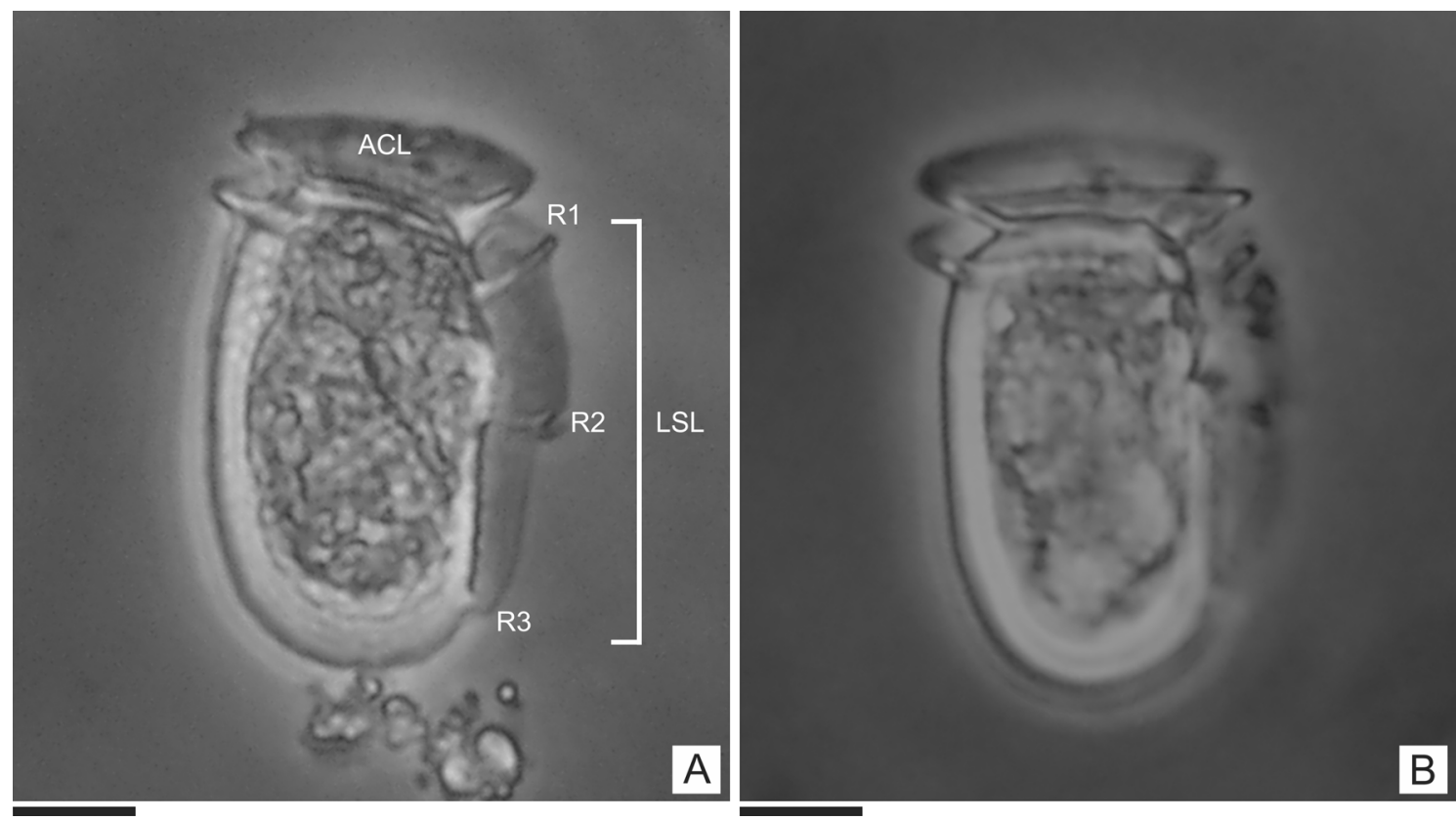

Fig. 2. LM images of Dinophysis microstrigiliformis. A-B: lateral views; note that the LSL is large (ends almost at the hypothecal antapex), R3 is shorter than R2 and the distance between R2 and R3 is larger than between R1 and R2. Abbreviations= LSL: left sulcal list. ACL: anterior cingular list. R: sulcal list rib. Scale bars: $10 \mu \mathrm{m}$. 


\section{E. Fabro \& G. O. Almandoz - Rare marine dinoflagellates}

Table 1. Summary of the occurrence, abundance, and physical conditions in which the reported dinoflagellate taxa were found. $\mathrm{n} / \mathrm{d}$ : not detected. $\mathrm{M}_{\mathrm{e}}$ : median. Relative contribution: abundance percentage of the analyzed taxa with respect to the total abundance of phytoplankton.

\begin{tabular}{|c|c|c|c|c|c|c|}
\hline Taxon & $\begin{array}{l}\text { Expedition and } \\
\text { station }\end{array}$ & Abundance & Temperature & Salinity & Total Phytoplankton & $\begin{array}{l}\text { Relative } \\
\text { contribution }\end{array}$ \\
\hline & & (cells $\mathrm{L}^{-1}$ ) & $\left({ }^{\circ} \mathrm{C}\right)$ & (psu) & (cells $\mathrm{L}^{-1}$ ) & $(\%)$ \\
\hline $\begin{array}{l}\text { Dinophysis } \\
\text { microstrigiliformis }\end{array}$ & E1: C20, 19, I22 & $\mathrm{n} / \mathrm{d}$ & 8.5 & $32.8 ; 33.3$ & $\begin{array}{c}113,500 ; 1,946,500 \\
969,400\end{array}$ & - \\
\hline Gyrodinium sp. & E3: 5,42 & 4,$900 ; 6,500$ & $8.0 ; 8.3$ & $33.7 ; 33.8$ & $2,750,900 ; 3,253,300$ & $0.2 ; 0.1$ \\
\hline Karlodinium elegans & E3: 5,43 & $\begin{array}{l}1,600 \\
14,600\end{array}$ & $8.0 ; 9.4$ & 33.7 & $2,750,900 ; 3,427,590$ & $0.05 ; 0.4$ \\
\hline Oxytoxum laticeps & $\begin{array}{l}\text { E1: I46, C16, I11, } \\
\text { I13, I14, I15 } \\
\text { E2: 3K2 } \\
\text { E3: } 15,43 \\
\text { E4: T1, T2, T3 } \\
\text { E5: } 7\end{array}$ & $\begin{array}{c}40-440 \\
\left(M_{e}=100\right)\end{array}$ & $\begin{array}{l}5.4-17.2 \\
\left(M_{e}=8.5\right)\end{array}$ & $\begin{array}{l}32.6-34.2 \\
\left(M_{e}=33.7\right)\end{array}$ & $\begin{array}{c}48,880-4,139,105 \\
\left(M_{e}=541,990\right)\end{array}$ & $\begin{array}{l}0.001-0.4 \\
\left(M_{e}=0.03\right)\end{array}$ \\
\hline Peridiniella spp. & $\begin{array}{l}\text { E1: C16,C21,I12, } \\
\text { I13, I14, I15, I48, } \\
\text { I49 } \\
\text { E2: 18K1, 21K2 } \\
\text { E3: } 1,2,3,5,6, \\
7,8,10-16,20, \\
27,30,31,37,38, \\
41-44,47,48 \\
\text { E4: T2, T3 } \\
\text { E5: } 2,4\end{array}$ & $\begin{array}{l}20-9,000 \\
\left(M_{e}=220\right)\end{array}$ & $\begin{array}{c}7.9-16.3 \\
\left(M_{e}=13.8\right)\end{array}$ & $\begin{array}{l}33.2-33.8 \\
\left(M_{e}=33.4\right)\end{array}$ & $\begin{array}{c}74,760-24,050,740 \\
\left(M_{e}=1,442,938\right)\end{array}$ & $\begin{array}{c}0.00007-0.54 \\
\left(M_{e}=0.02\right)\end{array}$ \\
\hline Prorocentrum nux & E2: 10K2 & 82 & 16.2 & - & 342,900 & 27 \\
\hline
\end{tabular}

microstrigiliformis is considered as a currently accepted taxonomic entity (Guiry \& Guiry, 2019). However, the morphological similarity with $D$. lapidistrigiliformis and D. sacculus might justify a taxonomic revision. In this sense, Reguera and González-Gil (2001) suggested that small and dimorphic cells of $D$. sacculus mentioned by Bardouil et al. (1991) probably corresponds to D. microstrigiliformis. Likewise, Haraguchi \& Odebrecht (2010) stated that $D$. lapidistrigiliformis may be a stage in the life cycle of $D$. fortii.

\section{Gyrodinium sp. Kofoid \& Swezy, 1921. Fig. 3.}

Ovoid to spindle cell shape, slightly dorsoventrally compressed. The epi- and hypocone are similar in size (Fig. 3A-C). The apex is rounded whereas the antapex can be rounded (Fig. 3B) or conical (Fig. 3C). The apical groove is elliptical and bisected into two equal parts by a central line (Fig. 3C). Cells are ornamented with longitudinal striations, with the same number of striae in the epiand hypocone, about 12 in ventral view. The sulcus is straight, narrow, well defined, and extends into the epicone. On the hypocone, the sulcus is well defined and deep, broadening toward the antapex. The cingulum is not superposed and only slightly displaced, about $1 / 10$ of the total cell length. The genus Gyrodinium contains only heterotrophic species (Daugbjerg et al. 2000). Dimensions: length average $11.5 \mu \mathrm{m} \pm 2.0$, width average $8.7 \mu \mathrm{m} \pm 1.9$ $(n=20)$.

Distribution and habitat. In the Argentine Sea, the genus Gyrodinium is mainly represented by G. fusus, a big species ( $\approx 80 \mu \mathrm{m}$ long) frequently 

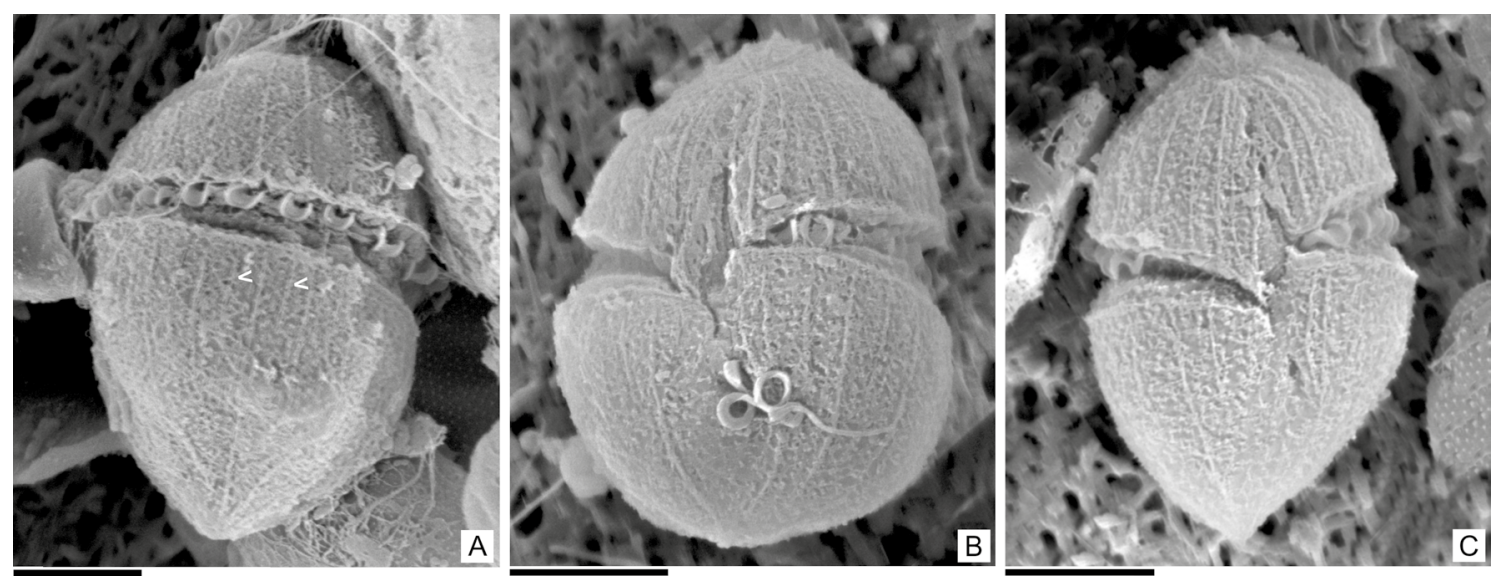

Fig. 3. SEM images of Gyrodinium sp. A: lateral view; note the faint stria in the hyposome among pairs of prominent striae (arrowheads). B-C: ventral views. Scale bars: $5 \mu \mathrm{m}$.

recorded in shelf waters from 36 to $39^{\circ} \mathrm{S}$, including estuarine areas (Akselman, 1985; Barría de Cao \& Piccolo, 2008). By contrast, the small Gyrodinium sp. cells found in this study were mainly observed in high salinity slope waters (St. 5 and 42 from E3, Table 1). In those samples, Gyrodinium sp.-like cells densities were $6.5 \times 10^{3}$ and $4.9 \times 10^{3}$ cells $\mathrm{L}^{-1}$, respectively (Table 1 ). At both stations, total plankton abundance was around $3 \times 10^{6}$ cells $\mathrm{L}^{-1}$ but species composition varied considerably: at station 5 diatoms were the dominant group, while at station 42 a bloom of the dinoflagellate Prorocentrum cordatum was observed.

Observations. The genus Gyrodinium was described by Kofoid \& Swezy (1921) to comprise unarmored dinoflagellates with a descent cingulum displaced by more than one-fifth of the total body length, in contrast to Gymnodinium which was defined by a cingulum displacement less than onefifth of the cell length. More recently, Daugbjerg et al. (2000) proposed the apical groove system as a more useful character to distinguish these genera, as cingular displacement varies even within clonal species (e.g., Takano \& Horiguchi, 2004). Consequently, the authors redefined Gyrodinium to contain exclusively heterotrophic species with an elliptical apical groove and longitudinal striations in the amphiesma surface, while Gymnodinium species have a horseshoe-shaped apical groove and no striations. From the about 100 species originally described as Gyrodinium, only $G$. helveticum, $G$. rubrum, G. spirale, G. fusiforme, G. moestrupii and G. jinhaense (Takano \& Horiguchi, 2004; Yoo et al., 2012; Jang et al., 2019), were assigned to Gyrodinium sensu Daugbjerg et al. (2000). The cells analyzed in this study showed an elliptical apical groove and longitudinal striations, which agrees with the above mentioned Gyrodinium definition, which has also been supported by phylogenetic analysis (Takano \& Horiguchi, 2004). Gyrodinium sp. cells found in this study resemble, in general shape and size (17 $\mu \mathrm{m}$ length, $12 \mu \mathrm{m}$ wide), the species G. carteretensis described by Campbell (1973). However, no striation is mentioned in the original description of $G$. carteretensis and the cingular displacement is bigger than in our specimens (1/3 vs. $1 / 10$ of the total cell length). Moreover, in the original description is established that cells present chloroplast, so this species does not agreed with the Gyrodinium definition by Daugbjerg et al. (2000). The recently described Gyrodinium jinhaense (Jang et al., 2019) is similar in size to the cells found in our study, especially considering $G$. jinhaense cells starved for 2 days (13-26 $\mu \mathrm{m}$ long, and 7-12 $\mu \mathrm{m}$ wide). However, $G$. jinhaense contour is more slender, the cingulum is displaced about one quarter of the cell length and the posterior sulcal area is widened toward the antapex, forming a slightly S-shaped line. Moreover, the cell surface in $G$. jinhaense is ornamented with 16 longitudinal striations in ventral view; while 


\section{E. Fabro \& G. O. Almandoz - Rare marine dinoflagellates}

in Gyrodinium sp. there are no more than 12. In one of our pictures (lateral view) one faint stria is present in the hyposome among pairs of prominent striae (Fig. 3A, arrowheads), thus resembling the species G. heterostriatum (sensu Gómez et al., 2020). However, cells in this study are considerably smaller than cells from $G$. heterostriatum; despite this species has a very wide size range $(30-70 \mu \mathrm{m}$ long; 25-60 $\mu \mathrm{m}$ wide). Moreover Gyrodinium sp. cells have a lower number of striae in the hypocone in ventral view (12 or less vs. about 25 ) and finally in $G$. heterostriatum the episome is smaller than the hyposome while in our species both are almost equal in size. Considering the above mentioned morphological and size differences compared to other similar Gyrodinium species, the cells observed in our study could not be assigned to species level. Additional molecular and morphological analyses are needed for a reliable identification.

Karlodinium elegans Cen, $\mathrm{Lu} \&$ Huang. $J$. Oceanol. Limnol. 39: 245. 2021. Fig. 4.

Ovoid cells with pointy apex, the epicone is conical and displays rows of parallel furrows that are twisted to the left side in relation to the cell longitudinal axis. Each epicone furrow carries rows of rounded structures ending in small pores (micro-processes sensu Paulmier et al., 1995; knobs sensu Cen et al., 2021) (Fig. 4A, B). The hypocone is rounded and its surface is ornamented with quadrilateral pits formed by longitudinal and horizontal stripes (Fig. 4C). The cingulum is displaced; its anterior side is delineated from the epicone by a list; below the cingulum the surface displays two parallel rows of knobs (Fig. 4C, arrows). The sulcus invades slightly the epicone as a finger-like protrusion (Fig. 4A, arrowhead). The apical groove begins ventrally, above the sulcus, is directed obliquely to the apex and extends to the middle region of the dorsal epicone (Fig. 4B, double arrowhead). The ventral pore is a thin and long slit located far from the apical groove at the left side of the sulcal region (Fig. 4D, triangle; Fig. 4E). This is an autotrophic species with several yellowish-brown chloroplasts distributed in the cell periphery (Cen et al., 2021). Dimensions: length average $14.9 \mu \mathrm{m} \pm 2.7$, width average 11.1 $\mu \mathrm{m} \pm 2.0(n=24)$.
Distribution and habitat. Karlodinium elegans was recently described based on two clonal cultures (PTB601 and PTB602) obtained from samples collected during a dinoflagellate bloom in Pingtan coastal area, Fujian, SE China. Our SEM analyses revealed the presence of $K$. elegans in bottle samples at stations 5 and 43 from E3, which correspond to relatively cold $\left(8-9.4{ }^{\circ} \mathrm{C}\right)$ slope waters at $\approx 40$ and $45^{\circ} \mathrm{S}$. In these samples, Karlodinium-like cells densities were $1.6 \times 10^{3}$ and $14.6 \times 10^{3}$ cells $\mathrm{L}^{-1}$ respectively (Table 1); total plankton abundances were $2.7 \times 10^{6}$ and $3.4 \times 10^{6}$ cells $\mathrm{L}^{-1}$. Both samples were dominated by diatoms, mainly Hemiaulus sp. and also Thalassiossira sp. at station 5.

Little is known about the occurrence of Karlodinium species, or the family Kareniaceae in general (De Salas et al., 2008 and references therein). Even though Kareniaceae representatives and other unarmored dinoflagellates may be a dominant component of the dinoflagellate flora in Antarctic (Gast et al., 2006, 2007; Mascioni et al., 2019) and Arctic waters (Luo et al., 2011), they are widely unrecognized in field surveys due to the potential for misidentification when applying only routine morphological analysis. For this reason, it is important to perform more deep morphological or molecular studies of this group, especially considering that several species in the lineage are known to be ichthyotoxic (Bergholtz et al., 2005).

Observations. The family Kareniaceae comprises three genera, i.e. Karlodinium, Karenia and Takayama, which share plastids with fucoxanthin and its derivatives as the major accessory pigments (De Salas et al., 2003; Benico et al., 2019). The genus Takayama possess a sigmoid apical groove (De Salas et al., 2003), while in Karlodinium and Karenia the groove is straight; although Karlodinium differs from Karenia by the presence of a ventral pore at the left side of the apical groove (Daugbjerg et al., 2000). The general appearance and main morphological features (e.g. long slit-like "ventral pore", longitudinal striations curving to the left side on the epicone, the apical groove extending to the middle region of the dorsal epicone, and a very special and unusual surface ornamentation on the hypocone) of Karlodinium cells analyzed in this work were identical to that reported in the original description of $K$. elegans. Regarding cells size, our specimens were a little smaller than 
Bol. Soc. Argent. Bot. 56 (2) 2021
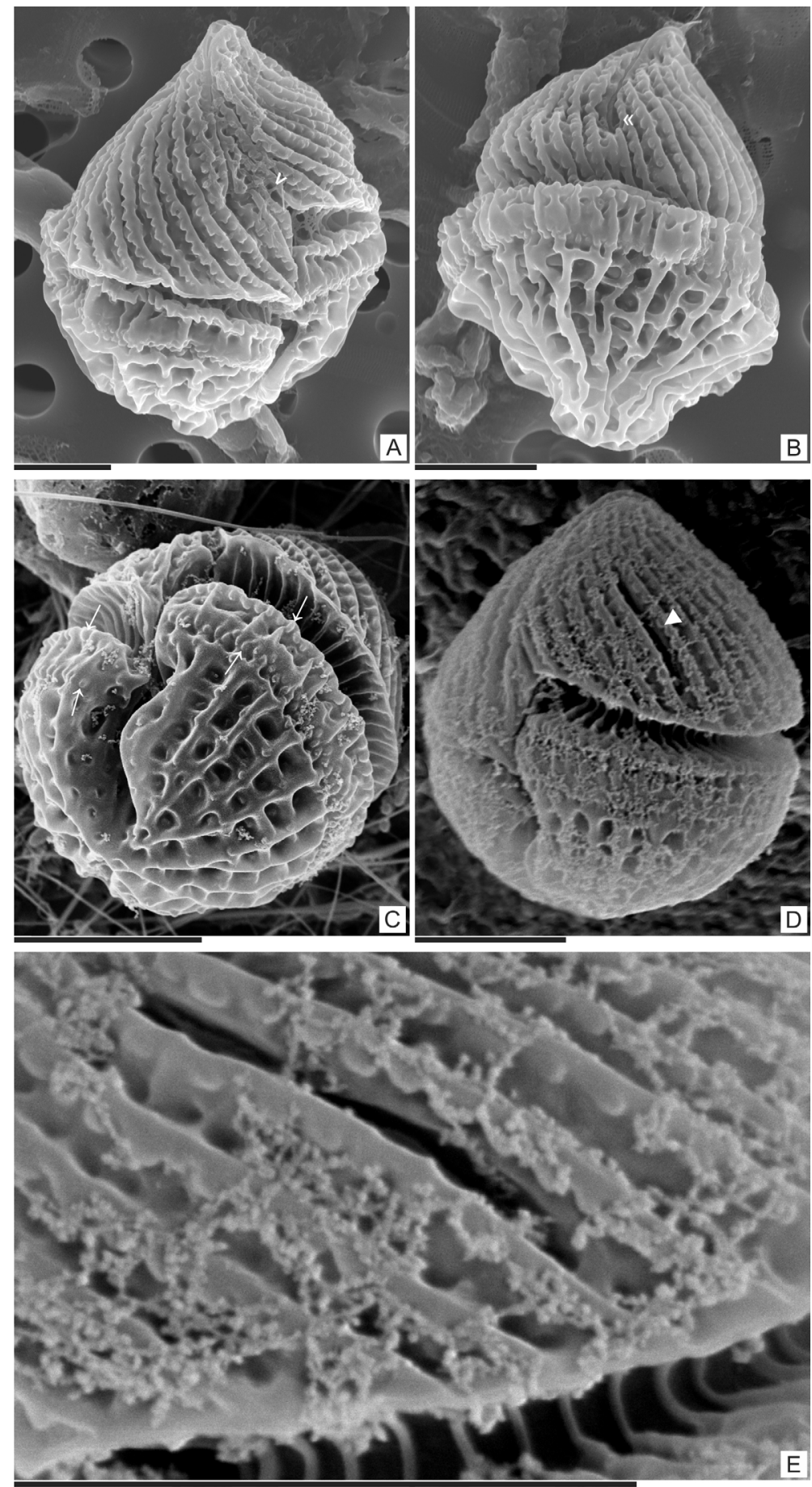

Fig. 4. SEM images of Karlodinium elegans. A: ventral view, note how the sulcus invades the epicone as a finger-like protrusion (arrowhead). B: dorsal view, note the apical groove ending in the dorsal region of the epicone (double arrowhead). C: antapical view, note the list in the anterior side of the cingulum, the ornamentation of longitudinal and horizontal stripes forming quadrilateral pits in the hypocone and the two rows of knobs in the upper hypocone and in the epicone striation (arrows). D: latero-ventral view, note that the ventral pore is a thin and long slit (triangle). E: detail of D showing the ventral slit. Scale bars: $5 \mu \mathrm{m}$. 


\section{E. Fabro \& G. O. Almandoz - Rare marine dinoflagellates}

those described by Cen et al. (2021), i.e. 19-27 $\mu \mathrm{m}$ long, $15-23 \mu \mathrm{m}$ wide. Morphologically two species of Karlodinium are similar to $K$ elegans: $K$. corrugatum and $K$. gentenii. All of them show parallel micro-processes rows below the cingulum. Particularly, K. corrugatum differs from K. elegans by presenting parallel and not twisted furrows in the epicone and $K$. gentenii has a ventral pore next the apical grove instead of a long slit (De Salas et al. 2008; Nézan et al., 2014). According to Nézan et al. (2014) a mixed fixation with Lugol's solution and glutaraldehyde allows to see fine details of the cell surface by removing the membranous material or mucilage that covers the cell. Likewise, Cen et al. (2021) established that the double fixation revealed a much clearer cell surface. Although cells analyzed in our study were fixed only with Lugol's solution, the main morphological features mentioned above could be observed. Unfortunately, the lack of samples preserved with other fixatives such as glutaraldehyde or osmium tetroxide did not allow performing a more detail examination of other key morphological features as the position and shape of the cell organelles.

Oxytoxum laticeps Schiller 1937, Fig. 5.

Burns \& Mitchell 1982, pp. 72-73, figs. 5-11; Gómez et al. 2008, p. 28, fig. 35.

The epitheca represents $20-26 \%$ of the total cell length, shows a domed shape, without apical spine, and it is smooth with occasional small pores arranged in random orientation (Fig. 5A-D). The hypotheca is cone-shaped, it is larger and wider than the epitheca, with convex sides which taper down to the antapex, ending in a pointy extension (Fig. 5AD). The cingulum is wide, deep, slightly displaced and presents well developed lists (Fig. 5C). The sulcal plate extends slightly into the hypotheca and a small sulcal wing covers the flagellar pores. (Fig. 5D). There is also a small ribbed list on the ventral and dorsal antapical end of the hypotheca (Fig. $5 \mathrm{C}, \mathrm{D})$. The hypothecal surface is covered with microtubular rods (sensu Burns \& Mitchell, 1982) arranged in rows from the antapex to the cingulum. The apical end of the tube is projected beyond the thecal plane and ends in a pore (Fig. 5C, D). It is an autotrophic species (Gómez et al., 2016). Dimensions: length average $16.7 \mu \mathrm{m} \pm 1.4$, width average $12.4 \mu \mathrm{m} \pm 1.8(n=20)$.
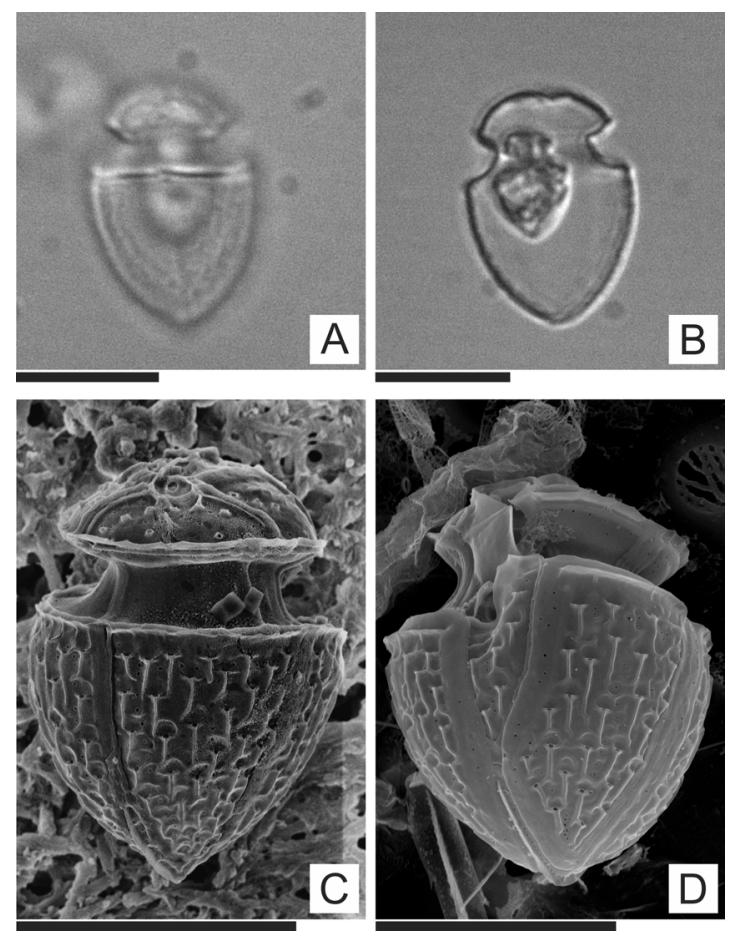

Fig. 5. LM (A-B) and SEM (C-D) images of Oxytoxum laticeps. C: dorsal view. Note the longitudinal ridges on the plates. D: ventral view. Note the small sulcal wing covering the flagellar pores. Scale bars: $10 \mu \mathrm{m}$.

Distribution and habitat. The species of the family Oxytoxaceae usually occur in low densities in the open ocean, and the smaller ones are rarely retained in net samples (Gómez, 2018). However, $O$. laticeps is commonly found in New Zealand coastal waters (Burns \& Mitchell, 1982), and densities up to $2.6 \times 10^{5}$ cells $\mathrm{L}^{-1}$ have been observed in Crozet Basin (Indian Ocean) (Kopczyńska \& Fiala, 2003). $O$. laticeps was described from the Mediterranean Sea and it was listed in the north, central equatorial, tropical and southeast Pacific (Hasle 1960; Venrick, 1982; Iriarte \& Fryxell, 1995; Gómez et al., 2008), in Canary Islands (northeast Atlantic) (Ojeda, 1996) and in the Caribbean Sea (Pérez-Castresana et al., 2014). Our finding represents the first record of $O$. laticeps for the southwest Atlantic Ocean, although Balech (1988) found one cell of the similar species $O$. mediterraneum at northeast Argentine Sea. O. laticeps was found in bottle samples during 
all expeditions but in low abundances and in a few stations (Table 1). Maximum cell densities (around 400 cells $\mathrm{L}^{-1}$ ) were detected during both summer expeditions in slope waters at the southern sampling area $\left(\approx 46-55^{\circ} \mathrm{S}\right)$, where total planktonic abundances of $\approx 1.3 \times 10^{6}$ cells $\mathrm{L}^{-1}$ were primarily represented by blooms of the diatom genus Pseudonitzschia (St 7 from E5) and small $(<5 \mu \mathrm{m})$ unidentified phytoflagellates (St. T2 from E4).

Observations. Oxytoxum and Corythodinium are the only two genera within the family Oxytoxaceae, which form their own clade within the dinokaryotic dinoflagellates according to molecular data (Gómez et al., 2016). Both genera are morphologically similar but can be distinguish by the position of the cingulum, always anterior in Oxytoxum and median or anterior in Corythodinium, and by the larger and broader epitheca in Corythodinium (Taylor, 1976). Although some species possess intermediate characteristics between both genera; molecular data support the generic separation (Gómez et al., 2016). Within the genus Oxytoxum, Dodge and Saunders (1985) designated $O$. laticeps as the type species of Section Excavatum (II), which comprises species with a reduced and domed epitheca and sulcus deeply excavated and partly covered by a large list composed of extensions of $\mathrm{Sd}$ and 6" plates and by a list which is an extension of 1 "'. The closest species to O. laticeps is $O$. mediterraneum, which was also described by Schiller (1937). The presence of rows of hexagonal pores on the hypotheca of $O$. mediterraneum, differentiate it from $O$. laticeps. Additionally, a spine process in the antapex is found only in $O$. laticeps and the epitheca of $O$. mediterraneum is more flattened (Schiller, 1937). Burns \& Mitchell (1982) analyzed New Zealand field material and found that these features that differentiate both species were found in the same specimen due to a multilayered structure of the theca, and consequently considered $O$. mediterraneum as a synonym of $O$. laticeps. More recently, Gómez (2018) reviewed the synonymy of the dinoflagellate genera Oxytoxum and Corythodinium and placed $O$. laticeps in a group composed by $O$. sphaeroideum and allied species that present a small size, rounded cell shape and absence of spines. The author remarked that there were lots of species misidentifications within Oxytoxum and Corythodinium in the past, and that the identity of $O$. laticeps remains unclear, but both $O$ mediterraneum and $O$. laticeps are considered as accepted names. Cell length measurements from our specimens were in the range mentioned by Burns \& Mitchell (1982) (15-25 $\mu \mathrm{m})$ and by Dodge \& Saunders $(1985)(15-20 \mu \mathrm{m})$, but were smaller than those mentioned in Gómez et al. (2008) (30 $\mu \mathrm{m})$. The surface morphological characteristics of the hypotheca agreed with that mentioned by Burns and Mitchell (1982) for cells with persistent outer wall, characterized by a system of microtubular rods arranged in slanting rows from the antapex to the girdle with a microtubule that ends in a small pore. Another morphologically similar species is Oxytoxum stropholatum (Dodge \& Saunders, 1995) which was placed into Corythodinium by Gomez (2018). Our specimens share with C. stropholatum the presence of a sulcal wing covering the flagellar pores, but differed in general cell size (24-25 $\mu \mathrm{m}$ long; 14-17 $\mu \mathrm{m}$ wide according to Dodge \& Saunders, 1995) and in the shape of the epitheca, which is flattened and only slightly narrower than the hypotheca in C. stropholatum, while the cells analyzed in this study present a domed shaped epitheca which is sharply narrower than the hypotheca.

Peridiniella danica (Paulsen) Okolodkov \& Dodge. Eur. J. Phycol 30. 1995. Fig. 6A-C

Glenodinium danicum Paulsen (Basionym) Okolodkov \& Dodge 1995, pp. 301-302, 304, figs. 1-11.

Plate formula is: Po, X, 4', 3a, 7", 6c, 4s, 6"', $2^{\prime \prime \prime}$. Cells are almost rounded. The thecal surface is slightly or deeply rough. Cingulum is deeply excavated, displaced one girdle width, and presents lists at both sides. Sulcus is concave with two lists, the left one more prominent than the right one (Fig. 6A). The apical pore plates are surrounded by a collar that extends ventrally to the sulcus, covering partially plate 1' (Figs. 6A-C). The apical pore complex consists of a central structure surrounded by a horseshoe-shaped plate (Po) and another small plate $(\mathrm{x})$ located in the ventral left region of the apical pore complex (Fig. 6B). Both epitheca and hypotheca show pores in the plates which can be arranged in straight rows that run through the edges of the plate or forming concentric rows (Fig. 6A, arrowhead). Intercalary plate $2 \mathrm{a}$ can be six-sided 


\section{E. Fabro \& G. O. Almandoz - Rare marine dinoflagellates}
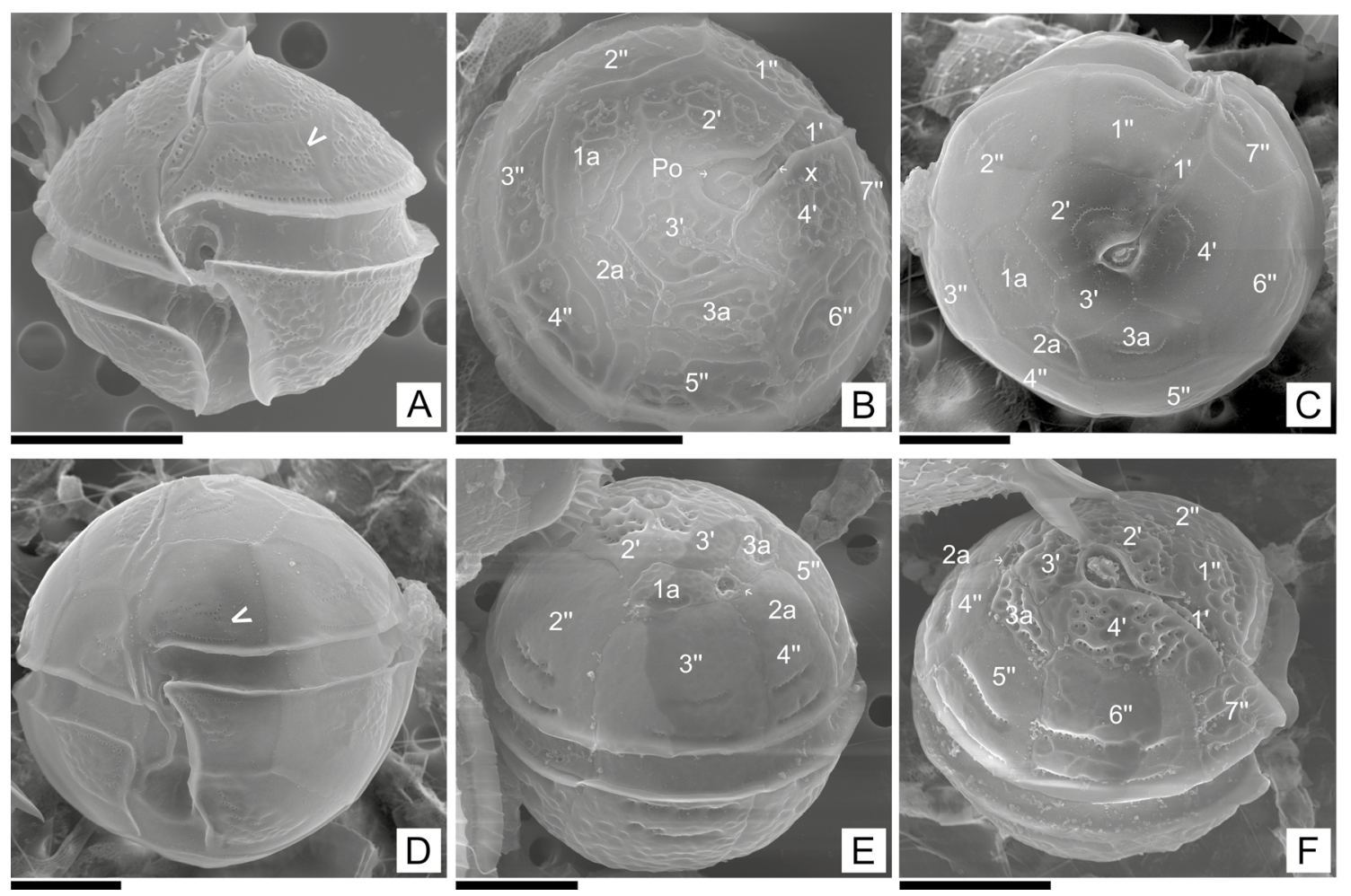

Fig. 6. SEM images of Peridiniella danica (A-C) and Peridiniella globosa (D-F). A: Ventral view, note the collar surrounding the apical pore plates and the arrangement of the pores on the theca surface (arrowhead). B-C: antapical views, note the different shape of plate $2 a$, hexagonal in B and pentagonal in C-D: Ventral view, note the collar surrounding the apical pore plates and the arrangement of the pores on the theca surface (arrowhead). E: Dorso-apical view, note the small plate 2a with a depression on the center. F: Apical view, note the small 2a plate. Scale bars: $10 \mu \mathrm{m}$.

(hexagonal) (Fig. 6B) or five-sided (pentagonal) (Fig. 6C). Autotrophic species. Dimensions: length average $23.9 \mu \mathrm{m} \pm 5.3(n=6)$, width average 22.0 $\mu \mathrm{m} \pm 6.1(n=5)$.

Peridiniella globosa (Dangeard) Okolodkov. Acta Bot. Mex. 74. 2006. Fig. 6D-F.

Peridinium globosum Dangeard (Basionym). Dangeard 1927 (as Peridinium globosum), p. 355, fig. 20 .

Plate formula is: Po, X, 4', 3a, 7", 6c, 4s, 6"', 2"'". Cells are rounded (Fig. 6D). The thecal surface is smooth or slightly rough. The collar surrounding the apical pore plates is not so evident in cells with a smooth theca. Cingulum is deeply excavated, displaced one girdle width and presents lists at both sides. Both epitheca and hypotheca show pores in the plates which can be arranged in straight rows that run through the edges of the plate or forming concentric rows (Fig. 6D, arrowhead). Intercalary plate $2 \mathrm{a}$ is pentagonal, very small and it is depressed with respect to the cell surface or shows a depression on the center (Fig. 6E, F). Autotrophic species. Dimensions: length average $31.3 \mu \mathrm{m} \pm 5.7(n=5)$, width average $32.2 \mu \mathrm{m} \pm 6.1(n=6)$.

Distribution and habitat. P. danica seems to be a cosmopolitan species, although it has been found mainly in cold waters, being widely distributed in the northeast Atlantic Ocean (Okolodkov \& Dodge, 1995 and references therein). Moreover, Peridiniella sp. recently mentioned for the western Antarctic Peninsula by Mascioni et al. (2019) 
corresponds to P. danica (Mascioni M., pers. com.). By contrast, $P$. globosa is listed in the Mexican Pacific (Okolodkov \& Gárate-Lizárraga, 2006) and in the Black Sea (Barinova et al., 2011). In the southwest Atlantic, the only Peridiniella species recorded, as far we know, is $P$. sphaeroidea found by Balech (1988) from $36^{\circ} \mathrm{S}$ to $39^{\circ} \mathrm{S}$ in temperate waters $\left(15-18{ }^{\circ} \mathrm{C}\right)$. In our study, Peridiniella spp. cells were observed during all expeditions, covering a wide area of the Argentine Sea $(\approx 39$ $54{ }^{\circ} \mathrm{S}$ ). Their abundance was usually low (e.g. from 20 to 1,960 cells $\mathrm{L}^{-1}$ ) in most expeditions, but peaks of $\approx 7 \times 10^{3}$ cells $\mathrm{L}^{-1}$ were recorded during spring at three stations (St. 37, 38 and 42) from southern slope waters. Maximum Peridiniella spp. abundances were detected in cold waters (8 ${ }^{\circ} \mathrm{C}$ ) (Table 1), which agrees with the background data mentioned above for $P$. danica.

The cell contour and size of Peridiniella species are very similar to species of the toxigenic genus Alexandrium (Okolodkov \& GárateLizárraga, 2006), and therefore, both taxa can be misidentified during routine cell counting with optical microscopy. In this study, Peridiniella spp. and Alexandrium spp. co-occurred in 19 samples from E3, in which Alexandrium sp. cell abundances ranged between 20 and 28,000 cells $\mathrm{L}^{-1}$. This highlights the importance of thecal plate observations during monitoring of harmful algae.

Observations. There are only four described species of Peridiniella: P. danica, P. catenata, $P$. sphaeroidea and P. globosa. All these species have a similar almost rounded cell shape and present the median and deep sulcus with lists in both margins, but they can be differentiated by the following characteristics: $P$. danica is slightly dorsoventrally compressed, $P$. catenata is characterized by the presence of antapical spines (Dodge, 1987), P. sphaeroidea shows a strong polygonal ornamentation over the surface of the thecal plates (Balech, 1979; Dodge, 1987), and $P$. globosa possess a very small second intercalary plate (2a) and a more globose cell contour than the other species (Dangeard, 1927; as Peridinium globosum). Observed cells of $P$. danica were similar in size to materials from the Norwegian Sea presented by Okolodkov \& Dodge (1995) (21-25 $\mu \mathrm{m}$ long, 20-22 $\mu \mathrm{m}$ wide). In accordance with these authors, we observed two different shapes of plate $2 \mathrm{a}$ (hexagonal or pentagonal) and two different arrangements of the pores (straight rows that run through the edges of the plate or forming concentric rows). By contrast, $P$. globosa showed a very small plate $2 \mathrm{a}$ and bigger size than $P$. danica. Plate $1^{\prime}$ of our specimens is narrower than that illustrated by Dangeard (1927; as Peridinium globosum).

Prorocentrum nux Puigserver \& Zingone. Phycologia 41. 2002. Fig. 7

Globose cell shape (Fig. 7A) and very convex valve shape (Fig. 7B, C). The periflagellar area is located on the right valve and is not depressed (Fig. 7D, E). The flagellar pore is bi-lobed and surrounded by seven plates (Fig. 7E). The surface of the valves is completely smooth, but shows small and large pores, usually with trichocysts emerging from them (Fig. 7E, F). The intercalary bands are well defined and overgrowth is evident in lateral view (Fig. 7D, $\mathrm{G}$, arrowheads). On the right valve, one small and three large pores are located in the apical zone, close to the periflagellar area (Fig.7-F), while both valves show a large pore and three small pores at the antapical extreme (Fig. 7G, H, arrows). Additionally, the left valve presents one small and two large pores grouped near the suture halfway between the apical and antapical ends (Fig. 7I, arrow). This is an autotrophic species with two ochre-yellow chloroplasts (Puigserver \& Zingone, 2002). Dimensions: length average 7.9 $\mu \mathrm{m} \pm 0.9(n=20)$, width average $7.3 \mu \mathrm{m} \pm 1.1(n$ $=20)$, depth average $7.8 \mu \mathrm{m} \pm 1.5(n=15)$.

Distribution and habitat. P. nux was described based on a culture (Pronap I) from the Tyrrhenian Sea in the Gulf of Naples (Puigserver \& Zingone, 2002). Another strain previously isolated from Plymouth waters (UK) in 1957 was also identified as P. nux by Puigserver \& Zingone (2002). By contrast, as far as we know, $P$. nux was never detected elsewhere since its original description, probably due to the extremely small size and very thin theca. In our study, very small and globose cells of a thecate dinoflagellate were observed in the San Matías Gulf (station 10K2 from E2, Table 1), and its abundance was estimated as 82,000 cells $\mathrm{L}^{-1}$. Further SEM analyses of bottle 


\section{E. Fabro \& G. O. Almandoz - Rare marine dinoflagellates}
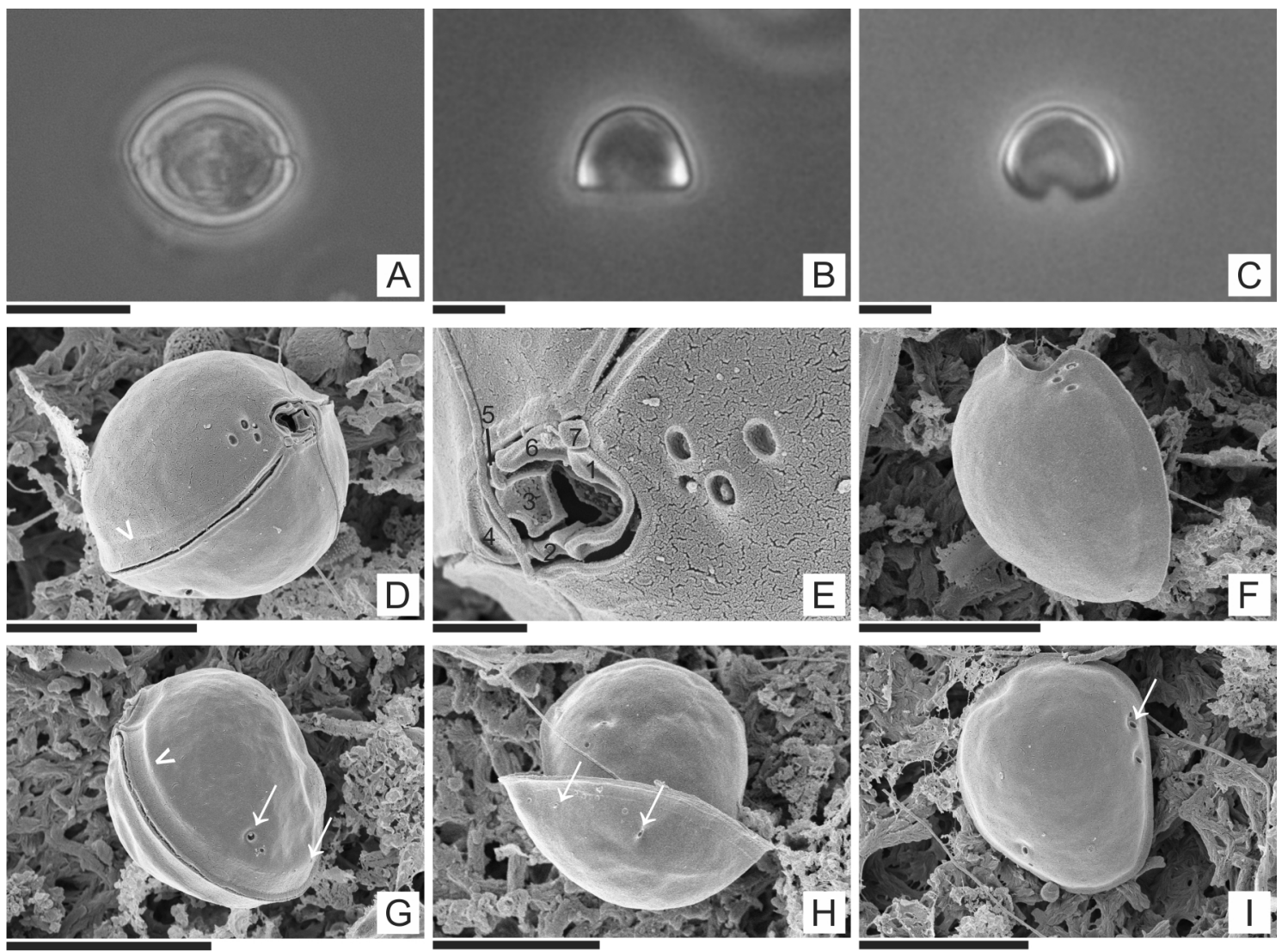

Fig. 7. LM (A-C) and SEM (D-I) images of Prorocentrum nux. A: Cell in lateral view. B: Empty valve in lateral view. C: Empty right valve in apical view. D: Whole cell, apical view. Note the overgrowth from the intercalary bands (arrowheads). E: Detail from 2, note the large pores and the small pore from the periflagellar area and the trichocysts emerging from them. F: Empty right valve. G: Whole cell, lateral view. Note the overgrowth from the intercalary bands (arrowheads) and the antapical group of pores (arrows). H: Whole broken cell, note the antapical group of pores (arrows). I: empty left valve, note the pores near the suture in the middle of the cell (arrow). Scale bars A-C, D, F-I: $5 \mu \mathrm{m} ; \mathrm{E}: 1 \mu \mathrm{m}$.

sample concentrates revealed that those cells corresponded to $P$. nux, a species that has never been quantified in field samples before. Total plankton abundance at station $10 \mathrm{~K} 2$ was $3 \times 10^{5}$ cells $\mathrm{L}^{-1}$ and was dominated by small $(<15 \mu \mathrm{m})$ dinoflagellates, of which Prorocentrum nux and Azadinium-like cells were the dominant taxa. Until now, there are no reports of harmful events related to $P$. nux, although is important to consider that small Prorocentrum species, such as $P$. cordatum, can produce dense blooms and generate anoxia and harmful effects on marine life (Heil et al., 2005).
Observations. P. nux has unique morphological characteristics that differentiate it from other Prorocentrum species, such as the globose shape in apical and antapical view, the overgrowth of the intercalary bands and the particular distribution of small and large pores (Puigserver \& Zingone, 2002). Cells analyzed in our study were similar in size to those provided in the original description (6.3-9.0 $\mu \mathrm{m}$ long, 5.3-10.0 $\mu \mathrm{m}$ wide), which placed $P$. nux as the smallest from all Prorocentrum species and even one of the smallest thecate dinoflagellates known until now. 


\section{Conclusions}

The detailed examination with optical and electron microscopy of field plankton samples collected in a large latitudinal and seasonal gradient across the Argentine Sea lead to the finding of seven dinoflagellate that are little known from marine waters worldwide. Most of them were rare or scarce; which, together with the requirement of detailed ultrastructural observations for their specific identification, justifies the poor information about their occurrence. However, Prorocentrum nux, which can be overlooked during routine microscopy examinations due to its very small size and thin theca, represented an important component of phytoplankton $\left(8.2 \times 10^{4}\right.$ cells $\left.\mathrm{L}^{-1}\right)$. Likewise, small unidentified specimens of Gyrodinium with distinctive morphological features were recorded in moderate densities $\left(4.9-6.5 \times 10^{3}\right.$ cells $\left.\mathrm{L}^{-1}\right)$. The results obtained in this study together with other recent findings from the same area suggest that the Argentine Sea presents high dinoflagellate diversity, and contribute to the understanding of global distribution patterns of small, usually rare and hard to detect dinoflagellate species.

\section{Author Contributions}

Both authors contributed to article conceptualization, microscopic analysis and writing.

\section{ACKNOWLEDgemENTS}

The authors thank the friendly reception and support of the crew of the R/V Puerto Deseado (CONICET-MINDEF, Argentina) in 2012 and 2013 of the R/V Bernardo Houssay (Prefectura Naval, Argentina) in 2013 and 2016 and of the R/V Coriolis II (ISMER-UQAMMcGill University- INRS/ETE-MLI/DFO, Canada) in 2014. Finally, we would like to thank both anonymous reviewers for their valuable comments and suggestions on the manuscript. This study was partially supported by PICT 02719 (ANPCyT) grant.

\section{BIBLIOGRAPHY}

ABÉ, T.H. 1967. The armoured Dinoflagellata: II. Prorocentridae and Dinophysidae (B) - Dinophysis and its allied genera. Publ. Seto Mar. Biol. Lab. 15: 37-78.

AKSELMAN, R. 1985. Contribución al estudio de la familia Gymnodiniaceae Lemmermann (Dinophyta) del Atlántico Sudoccidental. Physis 43: 39-50.

AKSELMAN, R. 1986. Contribución al conocimiento de la familia Warnowiaceae Lindenmann (Clase Dinophyceae) del Atlántico sudoccidental. Darwiniana 27: 9-17.

AKSELMAN, R. 1987. Quistes planctónicos de Dinofíceas en áreas de plataforma del Atlantico sudoccidental. I. Reporte taxonómico de la Familia Peridiniaceae Ehrenberg. Bol. Inst. Paul. Oceanogr. 35: 17-32.

AKSELMAN, R. \& R. NEGRI. 2012. Blooms of Azadinium cf. spinosum Elbrächter et Tillmann (Dinophyceae) in northern shelf waters of Argentina, Southwestern Atlantic. Harmful Algae 19: 30-38. https://dx.doi.org/10.1016/j.hal.2012.05.004

AKSELMAN, R, B. KROCK, T.J. ALPERMANN, U. TILLMANN, M. BOREL, G.O. ALMANDOZ, \& M.E. FERRARIO. 2015. Protoceratium reticulatum (Dinophyceae) in the austral southwestern Atlantic and the first report on YTX-production in shelf waters of Argentina. Harmful Algae 45: 40-52. https://dx.doi.org/10.1016/j.hal.2015.03.001

ANTACLI, J.C., R.I. SILVA, A.J. JAUREGUIZAR, D.R. HERNÁNDEZ, M. MENDIOLAR, M.E. SABATINI \& R. AKSELMAN. 2018. Phytoplankton and protozooplankton on the southern Patagonian shelf (Argentina, $47^{\circ}-55^{\circ} \mathrm{S}$ ) in late summer: potentially toxic species and community assemblage structure linked to environmental features. J. Sea Res. 140: 6380. https://dx.doi.org/10.1016/j.seares.2018.07.012

BALECH, E. 1976. Clave ilustrada de dinoflagelados Antárticos. Instituto Antártico Argentino (IAA), Buenos Aires, Argentina.

BALECH, E. 1979. Dinoflagelados campaña oceanográfica Argentina, Islas Orcadas. Armada Argentina Servicio de Hidrografia Naval 655: 1-76.

BALECH, E. 1988. Los dinoflagelados del Atlántico Sudoccidental. Publicaciones Especiales del Instituto Español de Oceanografía, Madrid, España.

BALECH, E. 1995. The genus Alexandrium Halim (Dinoflagellata). Sherkin Island Marine Station, Cork, Ireland. 


\section{E. Fabro \& G. O. Almandoz - Rare marine dinoflagellates}

BALECH, E., 2002. Dinoflagelados tecados tóxicos del cono sur americano. In: Sar, E. A., Ferrario, M. E., Reguera, B. (Eds.), Floraciones Algales Nocivas en el Cono Sur Americano. Instituto Español Oceanográfico de Madrid, Vigo, pp. 125-144.

BALECH, E., R. AKSELMAN, H.R. BENAVIDES \& R.M. NEGRI. 1984. Suplemento a "Los dinoflagelados del Atlántico Sudoccidental”. Rev. Investigación y Desarrollo Pesquero INIDEP 4: 5-20.

BARDOUIL, M., B. BERLAND, D. GRZEBYK \& P. LASSUS. 1991. L'existence de kystes chez les Dinophysiales. C. R. Acad. Sci. Paris Ser. III. 312: 663-669.

BARINOVA, S.S., L. KUKHALEISHVILI, E. NEVO \& Z. JANELIDZE. 2011. Diversity and ecology of algae in the Algeti National Park as a part of the Georgian system of protected areas. Turk. J. Bot. 35: 729-774. https://dx.doi.org/10.3906/bot-1009-83

BARRÍA DE CAO, S. \& C. PICCOLO. 2008. Presencia y variación estacional del dinoflagelado heterótrofo Gyrodinium fusus (Meunier) Akselman en el estuario de Bahía Blanca, Argentina. Atlántica, Rio Grande 30: 129137. https://dx.doi.org/10.5088/atlântica.v30i2.1512

BENICO, G., TAKAHASHI, K., LUM, W. M. \& IWATAKI, M. 2019. Morphological variation, ultrastructure, pigment composition and phylogeny of a star-shaped dinoflagellate Asterodinium gracile (Kareniaceae, Dinophyceae). Phycologia 58: $405-$ 18. https://doi.org/10.1080/00318884.2019.1601948

BERGHOLTZ, T., N. DAUGBJERG, Ø. MOESTRUP \& M. FERNÁNDEZ-TEJEDOR. 2005. On the identity of Karlodinium veneficum and description of Karlodinium armiger sp. nov. (Dinophyceae), based on light and electron microscopy, nuclear-encoded lsu rdna, and pigment composition. J. Phycol. 42: 170-193. https://dx.doi.org/10.1111/j.1529-8817.2006.00172.x

BOUTRUP, P.V., Ø., MOESTRUP, U. TILLMANN, \& N. DAUGBJERG. 2017. Ultrastructure and phylogeny of Kirithra asteri gen. et sp. nov. (Ceratoperidiniaceae, Dinophyceae) -a free-living, thin-walled marine photosynthetic dinoflagellate from Argentina. Protist 168: 586-611. https://dx.doi.org/10.1016/j.protis.2017.08.001

BURNS, D.A. \& J.S. MITCHELL. 1982. Some coastal marine dinoflagellates from around New Zealand. New Zealand J. Mar. Freshwater Res. 16: 69-79.

CEN, J., J. WANG, L. HUANG, Y. LIN, G. DING, Y. QI, \& S. LV. 2021. Karlodinium elegans sp. nov. (Gymnodiniales, Dinophyceae), a novel species isolated from the East China Sea in a dinoflagellate bloom. J. Oceanol. Limnol. 39: 242-258. https://doi.org/10.1007/s00343-020-0221-4

CAMPBELL, P.H. 1973. Studies on brackish water phytoplankton. Sea Grant Publ., University of North Carolina, NC.

DANGEARD, P. 1927. Phytoplancton de la croisière du Sylvana (Fevrier-juin 1913). Ann. Inst. Océanogr. 4: 285-407.

DAUGBJERG, N, G. HANSEN, J. LARSEN \& Ø. MOESTRUP. 2000. Phylogeny of some major genera of dinoflagellates based on ultrastructure and partial LSU rDNA sequence data, including the erection of 3 new genera of unarmored dinoflagellates. Phycologia 39: 302-317.

https://dx.doi.org/10.2216/i0031-8884-39-4-302.1

DE SALAS, M.F., C.J.S. BOLCH, L. BOTES, G. NASH, S.W. WRIGHT \& G.M. HALLEGRAEFF. 2003. Takayama gen. nov. (Gymnodiniales, Dinophyceae), a new genus of unarmored dinoflagellates with sigmoid apical grooves, including the description of two new species. J. Phycol. 39: 1233-46. https://dx.doi.org/10.1111/j.0022-3646.2003.03-019.x

DE SALAS, M.F., A. LAZA-MARTINEZ \& G.M. HALLEGRAEFF. 2008. Novel unarmored dinoflagellate from the toxigenic family Kareniaceae (Gymnodiniales): five new species of Karlodinium and one new Takayama from the Australian sector of the Southern Ocean. J. Phycol. 44: 241-257. https://dx.doi.org/10.1111/j.1529-8817.2007.00458.x

DODGE, J.D. 1987. An SEM study of Peridiniella sphaeroidea and P. catenata (Dinophyceae). Arch. Protistenk. 134: 139-148.

DODGE, J.D. \& R.D. SAUNDERS 1985. A partial revision of the genus Oxytoxum (Dinophyceae) with the aid of scanning electron microscopy. Bot. Mar. 28: 99-122.

FABRO, E., G.O. ALMANDOZ, M.E. FERRARIO, M.S. HOFFMEYER, R.E. PETTIGROSSO, R. UIBRIG \& B. KROCK. 2015. Co-occurrence of Dinophysis tripos and pectenotoxins in Argentinean shelf waters. Harmful Algae 42: 25-33. https://dx.doi.org/10.1016/j.hal.2014.12.005

FABRO, E., G.O. ALMANDOZ, M.E. FERRARIO, U. TILLMANN, A.D. CEMBELLA, \& B. KROCK. 2016. Distribution of Dinophysis species and their association with lipophilic phycotoxins in plankton from the Argentine Sea. Harmful Algae 59: $31-41$. https://dx.doi.org/10.1016/j.hal.2016.09.001 
FABRO, E., G.O. ALMANDOZ, M.E. FERRARIO, U. JOHN, U. TILLMANN, K. TOEBE, B. KROCK \& A. CEMBELLA. 2017. Morphological, molecular, and toxin analysis of field populations of Alexandrium genus from the Argentine Sea. $J$. Phycol. 53: 1206-1222.

https://dx.doi.org/10.1111/jpy.12574

FABRO, E., G.O. ALMANDOZ, B. KROCK \& U. TILLMANN. 2019. Field observations of the dinoflagellate genus Azadinium and azaspiracid toxins in the south-west Atlantic Ocean. Mar. Freshwater Res. 71: 832-843. https://doi.org/10.1071/MF19124.

GAST, R.J., D.M. MORAN, D.J. BEAUDOIN, J.N. BLYTHE, M.R. DENNETT \& D.A. CARON. 2006. Abundance of a novel dinoflagellate phylotype in the Ross Sea, Antarctica. J. Phycol. 42: 233-42. https://dx.doi.org/10.1111/j.1529-8817.2006.00183.x

GAST, R.J., D.M. MORAN, M.R. DENNETT \& D.A. CARON. 2007. Kleptoplasty in an Antarctic dinoflagellate: caught in evolutionary transition. Environm. Microbiol. 9: 39-45 https://dx.doi.org/10.1111/j.1462-2920.2006.01109.x

GÓMEZ, F. 2018. A review on the synonymy of the dinoflagellate genera Oxytoxum and Corythodinium (Oxytoxaceae, Dinophyceae). Nova Hedwigia 107: 141-165.

https://dx.doi.org/10.1127/nova_hedwigia/2017/0460

GÓMEZ, F., H. CLAUSTRE \& S. SOUISSI. 2008. Rarely reported dinoflagellates of the genera Ceratium, Gloeodinium, Histioneis, Oxytoxum and Prorocentrum (Dinophyceae) from the open southeast Pacific Ocean. Revista Biol. Mar. Oceanogr. 43: 25-40.

GÓMEZ, F., K.C. WAKEMAN, A. YAMAGUCHI \& H. NOZAKI. 2016. Molecular phylogeny of the marine planktonic dinoflagellate Oxytoxum and Corythodinium (Peridiniales, Dinophyceae). Acta Protozool. 55: 239-248.

https://dx.doi.org/10.4467/16890027AP.16.026.6095

GÓMEZ, F., L.F. ARTIGAS, \& R. GAST. 2020. Phylogeny and synonymy of Gyrodinium heterostriatum comb. nov. (Dinophyceae), a common unarmored dinoflagellate in the world oceans. Acta Protozoologica 59: 77-87. https://dx.doi.org/10.4467/16890027AP.20.007.12675

GRAHAM, L.E. \& L.W. WILCOX. 2000. Algae. Prentice-Hall, Upper Saddle River, New Jersey.

GUIRY, M.D. \& G.M. GUIRY. 2019. AlgaeBase. Worldwide electronic publication, National University of Ireland, Galway. [online]. Disponible en: http:// www.algaebase.org [Acceso: 05 September 2019].

HACKETT, J.D., D.M. ANDERSON, D.L. ERDNER \& D. BHATTACHARYA. 2004. Dinoflagellates: a remarkable evolutionary experiment. Amer. J. Bot. 91: 1523-1534.

https://dx.doi.org/10.3732/ajb.91.10.1523

HARAGUCHI, L. \& C. ODEBRECHT. 2010. Dinophysiales (Dinophyceae) no extremo Sul do Brasil (inverno de 2005, verão de 2007). Biota Neotrop. 10: 101-114. https://dx.doi.org/10.1590/S1676-06032010000300011

HASLE, G.R. 1960. Phytoplankton and ciliate species from the tropical Pacific. Skrifter utgitt av Det Norske Videnskaps Akademi Oslo 2: 1-50.

HEIL, C.A., P.M. GLIBERT \& C. FAN. 2005. Prorocentrum minimum (Pavillard) Schiller: a review of a harmful algal bloom species of growing worldwide importance. Harmful Algae 4: 449-470. https://dx.doi.org/10.1016/j.hal.2004.08.003

IRIARTE, J.L. \& G.A. FRYXELL. 1995. Microplankton at the equatorial Pacific $\left(140^{\circ} \mathrm{W}\right)$ during the JGOFS EqPac Time Series studies: March to April and October 1992. Deep Sea Res. II 42: 559-583.

IVIN, V.V., A.Y. ZVYAGINTSEV \& I.A. KASHIN. 2014. Monitoring and control of alien species in marine and insular specially protected areas by the example of the Far East Marine State Natural Biosphere Reserve. Russ. J. Biol. Invasions 5: 156-175. https://doi.org/10.1134/S2075111714030060

JANG, S.H., H.J. JEONG, M.J. LEE, J.H. KIM \& J.H. YOU. 2019. Gyrodinium jinhaense n. sp., a new heterotrophic unarmored dinoflagellate from the coastal waters of Korea. J. Eukar. Microbiol. 66: 821-835.

https://dx.doi.org/10.1111/jeu.12729

KOFOID, C.A. \& O. SWEZY. 1921. The free-living unarmored Dinoflagellata. Univ. Calif. Press., Berkeley, California.

KOPCZYŃSKA, E.E. \& M. FIALA. 2003. Surface phytoplankton composition and carbon biomass distribution in the Crozet Basin during austral summer of 1999: variability across frontal zones. Polar Biol. 27: 17-28. https://doi.org/10.1007/s00300-003-0564-2

LASSUS, P., N., CHOMÉRAT, E., NÉZAN \& P. HESS. 2016. Toxic and harmful microalgae of the World Ocean. Micro-algues toxiques et nuisibles de l'océan mondial. IOC Manuals and Guides 68 (English/French), Intl. Society for the Study of Harmful Algae (ISSHA) / Intergovernmental Oceanographic Commission of UNESCO (IOC), Copenhagen, Denmark. 


\section{E. Fabro \& G. O. Almandoz - Rare marine dinoflagellates}

LUO, W, C. DAI, H. LI \& X.Y. GAO. 2011. Phylogenetic diversity of dinoflagellates in polar regions. Advances in Polar Science 1: 35-41. https://dx.doi.org/10.3724/SP.J.1085.2011. 00035

MASCIONI, M., G.O. ALMANDOZ, A.O. CEFARELLI, A. CUSICK, M.E. FERRARIO \& M. VERNET. 2019. Phytoplankton composition and bloom formation in unexplored nearshore waters of the western Antarctic Peninsula. Polar Biol. 42: 1859-1872. https://doi.org/10.1007/s00300-019-02564-7

NÉZAN, E., R. SIANO, S. BOULBEN, C. SIX, G. BILIEN, K. CHÈZE, A. DUVAL, S. LE PANSE, J. QUÉRÉ \& N. CHOMÉRAT. 2014. Genetic diversity of the harmful family Kareniaceae (Gymnodiniales, Dinophyceae) in France, with the description of Karlodinium gentienii sp. nov.: a new potentially toxic dinoflagellate. Harmful Algae 40: 75-91.

https://dx.doi.org/10.1016/j.hal.2014.10.006

OJEDA, A. 1996. Biomasa planctónica y clorofila a en las Islas Canarias Occidentales. Mayo 1986. In: LLINÁS, O., J.A. GONZÁLEZ, \& M.J. RUEDA (eds.), Oceanografía y Recursos Marinos en el Atlántico Centro-Oriental, pp. 91-121. Instituto Canario de Ciencias Marinas, Cabildo Insular de Gran Canaria.

OKOLODKOV,Y.B.\& J.D.DODGE. 1995. Redescription of the planktonic dinoflagellate Peridiniella danica (Paulsen) comb. nov. and its distribution in the N. E. Atlantic. Eur. J. Phycol. 30: 299-306.

OKOLODKOV, Y.B. \& I. GÁRATE-LIZÁRRAGA. 2006. An annotated checklist of dinoflagellates (Dinophyceae) from the Mexican Pacific. Acta Bot. Mex. 72: 1-154.

PAULMIER, G., B. BERLAND, C. BILLARD \& E. NEZAN. 1995. Gyrodinium corsicum nov. sp. (Gymnodiniales, Dinophycées), organisme responsible d'une "eau verte" dans l'étang marin de Diana (Corse), en Avril 1994. Cryptog. Algol. 16: 77-94.

PÉREZ-CASTRESANA, G., E. VILLAMIZAR, R.VARELA \& Y. FUENTES. 2014. Descripción preliminar del fitoplancton en seis arrecifes coralinos del parque nacional Archipiélago de Los Roques. Acta Biol. Venez. 34: 293-309.

PUIGSERVER, M. \& A. ZINGONE. 2002. Prorocentrum nux sp. nov. (Dinophyceae), a small planktonic dinoflagellate from the Mediterranean Sea, and discussion of $P$. nanum and P. pusillum. Phycologia 41: 29-38.

https://doi.org/10.2216/i0031-8884-41-1-29.1
REGUERA, B. \& S. GONZÁLEZ-GIL. 2001. Small cell and intermediate cell formation in species of Dinophysis (Dinophyceae, Dinophysiales). J. Phycol. 37: 318-333. https://doi.org/10.1046/j.15298817.2001.037002318.x

SCHILLER, J. 1937. Dinoflagellatae (Peridineae) in monographischer Behandlung. In: RABENHORST, L. (ed.), Kryptogamen-Flora von Deutschland, Österreichs und der Schweiz, Volume 2, pp. 1-589. Akad. Verlag., Leipzig, Germany.

SCHNEPF, E., ELBRÄICHTER, M. 1988. Cryptophycean-like double membrane-bound chloroplast in the dinoflagellate Dinophysis Ehrenb.: Evolutionary, phylogenetic and toxicological implications. Bot. Acta 101: 196-203.

STEIDINGER, K.A. \& K. TANGEN. 1997. Dinoflagellates. In: TOMAS, C. (Ed.) Identifying Marine Phytoplankton. Academic Press, San Diego.

SUNESEN, I., F. RODRÍGUEZ HERNÁNDEZ, D. AGUIAR JUÁREZ, J. TARDIVO KUBIS, A. LAVIGNE, A. ROSSIGNOLI, P. RIOBÓ \& E. SAR. 2020a. Morphology, genetics and toxin profile of Prorocentrum texanum (Dinophyceae) from Argentinian marine coastal waters. Phycologia 59: 634-650.

https://dx.doi.org/10.1080/00318884.2020.1830552

SUNESEN, I., F. RODRÍGUEZ HERNÁNDEZ,

J. TARDIVO KUBIS, D. AGUIAR JUÁREZ, A. RISSO, A. LAVIGNE, S. WIETKAMP, U. TILLMANN \& E. SAR. 2020b. Morphological and molecular characterization of Heterocapsa claromecoensis sp. nov. (Peridiniales, Dinophyceae) from Buenos Aires coastal waters (Argentina). Eur. J. Phycol. 55: 490-506. https://doi.org/10.1080/09670262.2020.1750059

TAKANO, Y. \& T. HORIGUCHI. 2004. Surface ultrastructure and molecular phylogenetics of four unarmored heterotrophic dinoflagellates, including the type species of the genus Gyrodinium (Dinophyceae). Phycol. Res. 52: 107-116. https://doi.org/10.1111/j.1440-183.2004.00332.x

TAYLOR, F.J.R.. 1976. Dinoflagellates from the International Indian Ocean Expedition. A report on material collected by R/V «Anton Bruun» 19631964. Biblioth. Bot. 132: 1-234.

TILLMANN, U. 2018. Electron microscopy of a 1991 spring plankton sample from the Argentinean Shelf reveals the presence of four new species of the Amphidomataceae (Dinophyceae). Phycol. Res. 66: 269-290. https://dx.doi.org/10.1111/pre.12225 
TILLMANN, U. \& R. AKSELMAN. 2016. Revisiting the 1991 algal bloom in shelf waters off Argentina: Azadinium luciferelloides sp nov. (Amphidomataceae, Dinophyceae) as the causative species in a diverse community of other amphidomataceans. Phycol. Res. 64: 160-175. https://dx.doi.org/10.1111/pre.12133

TILLMANN, U., C.M. BOREL, F. BARRERA, R. LARA, B. KROCK, G.O, ALMANDOZ, M. WITT \& N. TREFAULT. 2016. Azadinium poporum from the Argentine Continental Shelf, Southwestern Atlantic, produces azaspiracid-2 and azaspiracid-2 phosphate. Harmful Algae 51: 40-55. https://doi.org/10.1016/j.hal.2015.11.001

TILLMANN, U., M. GOTTSCHLING, V. GUINDER \& B. KROCK. 2018. Amphidoma parvula (Amphidomataceae), a new planktonic dinophyte from the Argentine Sea. Eur. J. Phycol. 53: 1428 .

https://dx.doi.org/10.1080/09670262.2017.1346205
TILLMANN, U., M. GOTTSCHLING, B. KROCK, K.F. SMITH \& V. GUINDER. 2019. High abundance of Amphidomataceae (Dinophyceae) during the 2015 spring bloom of the Argentinean Shelf and a new, non-toxigenic ribotype of Azadinium spinosum. Harmful Algae 84: 244-260. https://dx.doi.org/10.1016/j.hal.2019.01.008.

UTERMÖHL, H. 1958. Zur Vervollkommnung der quantitativen Phytoplankton Methodik. Internationale Vereinigung für theoretische und angewandte Limnologie 9: 1-38.

VENRICK, E.L. 1982. Phytoplankton in an oligotrophic ocean: observations and questions. Ecol. Monogr. 52: 129-154.

YOO, Y.D., E.Y. YOON, H.J. JEONG, K.H. LEE, Y.J. HWANG, K.A. SEONG, J.S. KIM \& J.Y. PARK. 2012. The newly described heterotrophic dinoflagellate Gyrodinium moestrupii, an effective protistan grazer of toxic dinoflagellates. J. Eukar. Microbiol. 60: 13-24. https://dx.doi.org/10.1111/jeu.12002 